\title{
Indolebutyric acid on boxwood propagation by stem cuttings ${ }^{(1)}$
}

\author{
LEANDRO MARCOLINO VIEIRA ${ }^{(2)^{*}}$, SILVANO KRUCHELSKI(2), \\ ERIK NUNES GOMES(3), KATIA CHRISTINA ZUFFELLATO-RIBAS ${ }^{(4)}$
}

\begin{abstract}
Buxus sempervirens L., popularly known as boxwood, is a woody shrub widely used in gardening and landscaping. One of the most important factors for $B$. sempervirens commercial production is its propagation. The objective of this study was to evaluate the effect of indolebutyric acid (IBA) concentrations on the adventitious rooting of semihardwood stem cuttings of the species. Branches with new shoots were collected from stock plants with approximately 17 years of growth. Stem cuttings of six centimeters in length with two leaves in the upper region were made with a straight cut at the apex and a bevel cut at the base. Cuttings bases were immersed for 10 seconds in hydroalcoholic solutions $\left(50 \% \mathrm{v} \mathrm{v}^{-1}\right)$ with IBA at $0,1500,3,000$ or $6,000 \mathrm{mg} \mathrm{L}^{-1}$. The cuttings were evaluated at 64 and 116 days after planting. Rooting, mortality, callus formation and sprouting percentages as well as root number and root length were measured. At 64 days, no significant percentage of rooting was observed in B. sempervirens stem cuttings and sprouting and callus formation were not significantly affected by the treatments. Keeping the cuttings in the greenhouse for 116 days led to rooting rates up to a $97.5 \%$, with no statistical difference among treatments. Root lengths and root numbers did not differ as a function of treatments. The required period for $B$. sempervirens stem cuttings rooting is around 116 days; IBA application does not affect rooting, survival or sprouting of $B$. sempervirens stem cuttings.
\end{abstract}

Keywords: auxin, Buxus sempervirens L., rooting, vegetative propagation.

\section{RESUMO}

Ácido indolbutírico na propagação de buxinho a partir de estacas caulinares

Buxus sempervirens L., popularmente conhecido como buxinho, é um arbusto lenhoso amplamente utilizado na jardinagem e paisagismo. Um dos fatores mais importantes para a produção comercial de B. sempervirens é a sua propagação. O objetivo deste trabalho foi avaliar o efeito das concentrações de ácido indolbutírico (AIB) no enraizamento adventício de estacas semilenhosas da espécie. Ramos com brotações do ano foram coletados de plantas com aproximadamente 17 anos de idade. As estacas foram confeccionadas com $6 \mathrm{~cm}$ de comprimento, contendo 2 folhas na região apical, com corte reto no ápice e corte em bisel na base. A base das estacas foi imersa por 10 segundos em soluções hidroalcoólicas $\left(50 \% \mathrm{v} \mathrm{v}^{-1}\right)$ com AIB nas concentrações de $0,1.500,3.000$ e $6.000 \mathrm{mg} \mathrm{L}^{-1}$. As estacas foram avaliadas aos: 64 e 116 dias após o plantio. Foram avaliadas as porcentagens de enraizamento, mortalidade, formação de calos e brotação, número de raízes e comprimento médio das raízes. Na primeira avaliação, aos 64 dias, não se observou porcentagem significativa de enraizamento nas estacas de $B$. sempervirens, e a formação de calos e brotações não foi significativamente afetada pelos tratamentos. A manutenção das estacas na casa de vegetação por 116 dias proporcionou uma taxa de enraizamento de até $97,5 \%$, não havendo diferença estatística entre os tratamentos. O comprimento das raízes e o número de raízes não diferiram em função dos tratamentos. O período requerido para o enraizamento de estacas de $B$. sempervirens é de aproximadamente 116 dias. A aplicação de AIB não afeta o enraizamento, sobrevivência e brotação em estacas de $B$. sempervirens. Palavras-chave: auxina; Buxus sempervirens L.; enraizamento; propagação vegetativa.

\section{INTRODUCTION}

Buxus sempervirens L. (Buxaceae), popularly known as boxwood, is a native species from the Mediterranean, East and China regions. It is a woody shrub, 2 to $5 \mathrm{~m}$ high, with narrow-oval, coriaceous bright leaves, widely used in gardening and landscaping (LORENZI et al., 2013). Since it is a perennial, compact, symmetric and slow-growing plant ( 7 to $15 \mathrm{~cm}$ per year), it is very widespread and used for topiary, exerting an important ornamental value in varied landscape functions (NIEMIERA, 2012).

There are also reports of this species use for medicinal purposes. Alkaloids extracted from the plant presented antioxidant, antiprotozoal, and cholinesterase and

DOI: http://dx.doi.org/10.14295/oh.v24i4.1185

${ }^{(1)}$ Received in 23/04/2018 and accepted in 14/09/2018

(2) Universidade Federal do Paraná (UFPR), Departamento de Fitotecnia e Fitossanitarismo, Curitiba- PR, Brazil. *Corresponding author: leandro. marcolino@ufpr.br

(3) Rutgers University, Department of Plant Biology, New Brunswick-NJ, United States of America.

(4) Universidade Federal do Paraná - UFPR, Departamento de Botânica, Curitiba-PR, Brazil.

Licensed by CC BY 4.0 
tyrosinase inhibitor activities (ACAR et al., 2007; ORHAN et al., 2012). Extracts from the plant were also reported as alternatives for complementary treatment of asymptomatic HIV virus carriers (DURANT et al., 1998).

One of the most important factors for B. sempervirens commercial production is the propagation. Vegetative propagation stands out for the maintenance of genetic characteristics of stock plants, uniformity and production precocity (SMARSI et al., 2008). Among the vegetative propagation methods, the propagation by stem cutting is characterized by its operational simplicity and low cost compared to other methods, as well as by its easy execution (HARTMANN et al., 2011; NUNES GOMES and KRINSKI, 2016b).

The process of adventitious rooting in stem cuttings is influenced by several factors, among them the application of plant growth regulators, a practice that has been very useful in the propagation of commercially important plants (BASTOS et al., 2004; TAIZ and ZEIGER, 2013). For commercial purposes, indolebutyric acid (IBA) is one of the main synthetic auxins used to promote root formation in cuttings (HARTMANN et al., 2011). The knowledge about the rooting capacity of plant species and their response to plant growth regulators allows obtaining more satisfactory results for plant propagation (FACHINELLO et al., 2005).

Although it is a very widespread species in Brazilian landscaping, scientific data on B. sempervirens propagation are still scarce, especially those regarding the use of plant growth regulators and the time required to rhizogenesis on stem cuttings. Providing these information is important in economic terms, since the use of synthetic auxins may be currently used unnecessarily or in disproportionate concentrations and the plants may be kept under greenhouse conditions for a longer period than is necessary for the regeneration of root and shoot tissues. In scientific terms, it is important to understand how the species responds physiologically when treated with synthetic auxin and the time required for the responses. Considering the above, the present study evaluated the effects of IBA concentrations on the adventitious rooting of semihardwood stem cuttings of B. sempervirens in two periods under greenhouse conditions.

\section{MATERIAL AND METHODS}

The plant material was collected on August 2016 in the municipality of Curitiba, state of Paraná, Brazil (coordinates: $25^{\circ} 24^{\prime} 53^{\prime \prime} \mathrm{S}, 49^{\circ} 18^{\prime} 12^{\prime \prime} \mathrm{W}, 934.6 \mathrm{~m}$ altitude). The climate of the region is classified as cfb (temperate with oceanic origin precipitation) without dry season, with fresh summers and moderate winter, according to the Köppen classification.

Branches with new shoots (late winter) were collected from 12 Buxus sempervirens stock plants (clones of a same plant) with approximately 17 years of growth. The plant material was collected at six o'clock in the morning, sprayed with water and conditioned in plastic bags to be transported to the Plant Macropropagation laboratory at the Federal University of Paraná, Curitiba, Brazil, where the cuttings were made. The plant material remained in the bags for about two hours until the stem cuttings were prepared. The experiment was carried out in a greenhouse at the Department of Botany, in the Biological Sciences Sector of the Federal University of Paraná, Curitiba, Brazil.

The stem cuttings were made with $6 \mathrm{~cm}$ length and approximately $2.8 \pm 0.1 \mathrm{~mm}$ diameter. The cuttings were prepared with 2 leaves in the upper region, with a straight cut at the apex and a bevel cut at the base. After the preparation, the cuttings were disinfested for 10 minutes in solution with $0.5 \%$ sodium hypochlorite and then washed in running water for 5 minutes. After this procedure, the cuttings bases were immersed for $10 \mathrm{~s}$ in hydroalcoholic solutions $\left(50 \% \mathrm{~V} \mathrm{~V}^{-1}\right)$ with indolebutyric acid (IBA) at concentrations $0 ; 1,500 ; 3,000$ and $6,000 \mathrm{mg} \mathrm{L}^{-1}$.

The cuttings were planted in polypropylene tubes ( 53 $\mathrm{cm}^{3}$ volume) containing fine granulometry vermiculite, previously moistened. During the experiment, the cuttings remained in a greenhouse with intermittent misting, with $80 \%$ relative humidity, temperature between 20 and 30 ${ }^{\circ} \mathrm{C}$ and $50 \%$ shading provided by the use of reflective aluminized shade fabric (Aluminet).

The experiment was installed in a completely randomized design, with 4 treatments and 4 replications with 20 cuttings as experimental unit, totalizing 320 stem cuttings in the experiment. The cuttings were evaluated in two periods: 64 and 116 days after planting. Rooting, mortality, callus formation and sprouting percentages as well as roots number and roots length (average of three largest roots) were measured.

Data were subjected to variance homogeneity analysis according to Bartlett's test. When homogenous, data were submitted to variance analysis (ANOVA) and, when significant, means where compared by the Tukey test at 5\% probability. The statistical software Assistat 7.7 (SILVA and AZEVEDO, 2016) was used to perform these analyses.

\section{RESULTS AND DISCUSSION}

On the first evaluation at 64 days, no significant percentage of rooting was observed in B. sempervirens stem cuttings. Notwithstanding, the fact that $100 \%$ of the cuttings were alive on this occasion, allowed them to remain in the greenhouse for a longer period of time.

Unlike the results obtained in this study, Takata et al. (2012) reported 55.8\% rooting in Duranta repens L. stem cuttings at 15 days after planting and $100 \%$ rooting after 30 days. Similarly, Loss et al. (2008) reported 52.8\% rooting in Allamanda cathartica L. cuttings at 14 days. These findings reinforce the need to study rooting dynamics on each species, since genetic characteristics can define the speed and potential for rooting in stem cuttings (OLIVEIRA et al., 2015).

The high survival percentage at 64 days might be related to the genus Buxus phytochemical, morphological and anatomical characteristics, which are extremely important for its climatic adaptation. According to Hormaetxe et al. (2007) B. sempervirens leaves have a photo-protective mechanism involving carotenoid related action in response to stress factors during summer. Such peculiarities are extremely important for this species propagation, since 
them allow cuttings survival rates to remain stable under greenhouse environmental conditions.

According to statistical analysis, IBA concentrations did not cause significant differences for any of the evaluated variables (Table 1). At 64 days, low sprouting percentages were observed (maximum $43.75 \%$ ). Sprouting is an important characteristic for yielding quality plants, since the presence of new shoots is essential for plant nutrition after the depletion of cutting reserves (NUNES GOMES and KRINSKI, 2016a).

Table 1. Percentages of Buxus sempervirens stem cuttings alive with callus, alive without callus formation and sprouting as a function of different concentrations of indolebutyric acid (IBA), at 64 days after planting.

\begin{tabular}{|c|c|c|c|}
\hline $\begin{array}{c}\text { IBA } \\
\left(\mathbf{m g ~ L}^{-1}\right)\end{array}$ & $\begin{array}{c}\text { Alive with callus } \\
(\mathbf{\%})\end{array}$ & $\begin{array}{c}\text { Alive without } \\
\text { callus }(\mathbf{\%})\end{array}$ & $\begin{array}{c}\text { Sprouting } \\
(\mathbf{\%})\end{array}$ \\
\hline 0 & 88.75 & 11.25 & 37.50 \\
\hline 1,500 & 90.00 & 10.00 & 38.75 \\
\hline 3,000 & 90.00 & 10.00 & 41.25 \\
\hline 6,000 & 97.50 & 2.50 & 43.75 \\
\hline F-test value & $0.97^{\text {ns }}$ & $0.97^{\text {ns }}$ & $0.17^{\text {ns }}$ \\
\hline CV $(\%)$ & 8.88 & 96.39 & 32.67 \\
\hline Bartlett test $\left(\chi^{2}\right)$ & $5.96^{\text {ns }}$ & $5.96^{\text {ns }}$ & $0.95^{\text {ns }}$ \\
\hline
\end{tabular}

Means followed by the same letter in the column do not differ statistically by the Tukey test at 5\% probability. ${ }^{\text {ns: }}$. non-significant (when applied to the Bartlett test, non-significance indicate homogenous variances - $\mathrm{H} 0$ non-rejected).

The high percentage of cuttings with callus formation in all treatments (from $88.75 \%$ to $97.5 \%$ ) at 64 days may suggest that $B$. sempervirens cuttings emit roots from callus. In Ginkgo Biloba, Bitencourt et al. (2007) observed that callus formation is a fundamental condition for the formation of adventitious roots in stem cuttings. In Maytenus ilicifolia Mart. Ex Reissek, however Lima et al. (2009) observed that callus formation does not occur in all minicuttings, confirming that it is not a prerequisite for root initiation.

Fachinello et al. (2005) stated that in most cases callus formation and adventitious root emission in stem cuttings are influenced by the same factors, which may lead them to occur simultaneously without being related to each other. The authors emphasize that the dependence on callus formation for adventitious root emission is a peculiarity of some species and not a general rule. Nevertheless, according to Bitencourt et al. (2010), in species that present difficulty on adventitious rooting, the callus formation usually occurs before rooting, which means that a longer period of time in the greenhouse will possibly result in higher percentages of root formation on such cuttings. The presence of callus in this context can be considered an indicator of a suitable rooting environment (NUNES GOMES and KRINSKI, 2016b).

Although $B$. sempervirens stem cuttings are considered to be easily rooted because they do not present anatomical barriers that prevent the formation of adventitious roots (GONZÁLEZ and DIAZ, 1986), B. sempervirens shows excessively slow growth, which may explain why 64 days were not enough to observe root formation. In other species, it was also observed that a 60 -day period was not enough for rooting. For Drimys brasiliensis rooting was only observed after 120 days from planting (ZEM et al., 2015), the same was reported for Caesalpinia echinata Lam (ENDRES et al., 2007).

In the present study, the longer maintenance of the cuttings in the greenhouse, allowed a $97.5 \%$ rooting rate, with no statistical difference between the treatments (Table 2). These responses show that, regardless of the IBA treatments, the stem cuttings have high rooting capacity, thus confirming that the fundamental issue in B. sempervirens vegetative propagation refers mainly to the required period for rooting and not to the supply of exogenous auxins. The fact that only apical cuttings were used in this experiment may also be an important factor contributing to high rooting percentages. In Stevia rebaudiana propagation, the use of apical cuttings is the most recommended because these cuttings present the highest concentrations of endogenous auxins (PIGATTO et al., 2018).

Similarly as observed in this study, the use of IBA did not affect the rooting of Jasminum polyanthum (SILVA et al., 2012), Drimys brasiliensis (ZEM et al., 2015), Campomanesia aurea O. Berg (EMER et al., 2016) and Varronia curassavica Jacq (BISCHOFF et al., 2017).

It was observed in the present study that callus formation preceded root emission in $97.7 \%$ of the cuttings, which may indicate that the species presents indirect rhizogenesis. However, no supporting data were found in current literature to describe the peculiar characteristics of calogenesis and root formation in B. sempervirens. 
Table 2. Rooting, root number, average root length (ARL), callus and sprouting formation percentages in Buxus sempervirens stem cuttings as a function of indolebutyric acid (IBA) concentrations at 116 days after planting.

\begin{tabular}{|c|c|c|c|c|c|}
\hline $\begin{array}{c}\text { IBA } \\
\left(\mathbf{m g ~ L}^{-\mathbf{1}}\right)\end{array}$ & $\begin{array}{c}\text { Rooting } \\
\mathbf{( \% )}\end{array}$ & Root number & $\begin{array}{c}\text { ARL } \\
(\mathbf{m m})\end{array}$ & $\begin{array}{c}\text { Callus } \\
(\mathbf{\%})\end{array}$ & $\begin{array}{c}\text { Sprouting } \\
(\mathbf{\%})\end{array}$ \\
\hline 0 & 97.50 & 3.73 & 25.45 & 95.00 & 51.25 \\
\hline 1,500 & 91.25 & 3.50 & 22.48 & 95.00 & 61.25 \\
\hline 3,000 & 97.50 & 3.56 & 21.46 & 92.50 & 60.00 \\
\hline 6,000 & 97.50 & 3.66 & 24.47 & 97.50 & 55.00 \\
\hline Valor de F & $1.93^{\text {ns }}$ & $0.29^{\text {ns }}$ & $0.97^{\text {ns }}$ & $0.40^{\text {ns }}$ & $0.45^{\text {ns }}$ \\
\hline CV $(\%)$ & 4.70 & 10.53 & 15.77 & 6.79 & 24.28 \\
\hline Bartlett test $\left(\chi^{2}\right)$ & $4.36^{\text {ns }}$ & $0.22^{\text {ns }}$ & $2.29^{\text {ns }}$ & $4.09^{\text {ns }}$ & $0.02^{\text {ns }}$ \\
\hline
\end{tabular}

Means followed by the same letter in the column do not differ statistically by the Tukey test at $5 \%$ probability. ${ }^{\text {ns: }}$ non-significant (when applied to the Bartlett test, non-significance indicate homogenous variances - $\mathrm{H} 0$ non-rejected).

Average root length and root number did not differ according to the treatments. Regarding root number, the values were relatively low (maximum 3.73 per cutting), which may characterize the low mitotic activity of the species. A similar result was observed by Zem et al. (2015), who obtained a maximum of 3.61 roots in semihardwood Drimys brasiliensis stem cuttings.

At 116 days from planting, no statistically significant difference was observed for cutting sprouting (maximum $60 \%$ ). In a study with Myrciaria dubia stem cuttings, Delgado and Yuyama (2010) showed that the species presents high rooting rates due to the fact that root formation occurs before sprouting. This behavior, according to the authors, allows the cuttings to allocate their reserves for root formation instead of sprouting. In the present study, however, the shoot development prior to root formation did not impair adventitious rooting, implying that in $B$. sempervirens root and shoot system formations are independent.

Buxus sempervirens propagation through stem cuttings is a valid alternative for its commercial propagation. However, future studies with rejuvenation techniques may be advantageous as they might allow keeping the cuttings in the greenhouse environment for a shorter period of time.

\section{CONCLUSIONS}

Buxus sempervirens stem cuttings can be considered easy to root in a greenhouse environment. The required period for rooting is around 116 days. The species does not present root formation at 64 days.

IBA treatments at 1,500;3,000 and 6,000 $\mathrm{mg} \mathrm{L}^{-1}$ do not affect rooting, survival and sprouting of $B$. sempervirens stem cuttings.

Buxus sempervirens L. stem cuttings undergo indirect rhizogenesis.

\section{ACKNOWLEDGEMENTS}

The authors would like to acknowledge the Brazilian Federal Agency for Support and Evaluation of Graduate Education - CAPES for the sponsorship of the research and for the scholarships granted.

\section{AUTHORS CONTRIBUTIONS}

L.M.V. (D0000-0002-9336-860x: study conception and design, acquisition, analysis and interpretation of data, manuscript draft and review. S.K. D0000-0002-3774-1641: study conception and design, acquisition, analysis and interpretation of data, manuscript draft and review. E.N.G. D0000-0002-7999-070x. interpretation of data, manuscript draft and critical review. K.C.Z-R. D0000-0001-6320-5773: study conception and design, manuscript critical review.

\section{REFERENCES}

ACAR, C.; ACAR, H.; EROĞLU, E. Evaluation of ornamental plant resources to urban biodiversity and cultural changing: A case study of residential landscapes in Trabzon city (Turkey). Building and Environment, v.42, n.1, p.218-229, 2007. DOI: http://dx.doi.org/10.1016/j. buildenv.2005.08.030.

BASTOS, D.C.; MARTINS, A.B.G.; SCALOPPI JUNIOR, E.J.; SARZI, I.; FATINANSI, J.C. Influence of indolbutyric acid on the rooting of top and base cuttings of star fruit (Averrhoa carambola L.) under intermitent mist. Revista Brasileira de Fruticultura, v.26, n.2, p.284-286, 2004. DOI: http://dx.doi.org/10.1590/S010029452004000200025. 
BISCHOFF, A.M.; VENDRAMIM, D.W.; NUNES GOMES, E.; ENGEL, M.L.; MAGGIONI, R.A.; ZUFFELLATO-RIBAS, K.C. Rooting of black sage cuttings according to different indole butyric acid concentrations and number of leaves. Revista de Ciências Agroveterinárias (Journal of Agroveterinary Sciences), v.16, n.1, p.41-47, 2017. DOI: http://dx.doi. org/10.5965/223811711612017041.

BITENCOURT, J.; MAYER, J.L.S.; ZUFFELLATORIBAS, K.C. Propagação vegetativa de Ginkgo biloba por alporquia. Revista Brasileira de Plantas Medicinais, v.9, n.2, p.71-74, 2007.

BITENCOURT, J.; ZUFFELLATO-RIBAS, K.C.; KOEHLER, H.S. Estaquia de Ginkgo biloba L. utilizando três substratos. Revista Brasileira de Plantas Medicinais, v.12, n.2, p.135-140, 2010. DOI: http://dx.doi.org/10.1590/ S1516-05722010000200002.

DELGADO, J.P.M.; YUYAMA, K. Comprimento de estaca de camu-camu com ácido indolbutírico para a formação de mudas. Revista Brasileira de Fruticultura, v.32, n.2, 2010. DOI: http://dx.doi.org/10.1590/S010029452010005000066.

DURANT, J.; CHANTRE, P.; GONZALEZ, G.; VANDERMANDER, J.; HALFORD, P.; ROUSSE, B.; GUÉDON, D.; REHELINIRINA, V.; CHAMARET, S.; MONTAGNIER,L; DELLAMONICA, P. Efficacy and safety of Boxus sempervirens L preparations in HIVinfected asymptomatic patients: a multicenter randomized double-blind placebo controlled trial. Phytomedicine, v.5, n.3, p.1-10, 1998. DOI: 1http://dx.doi.org/0.1016/S09447113(98)80052-4.

EMER, A.A.; SCHAFER, G.; AVRELLA, E.D.; DELAZERI, M.; VEIT, P.A.; FIOR, C.S. Influence of indolebutyric acid in the rooting of Campomanesia aurea semihardwood cuttings. Ornamental Horticulture, v.22, n.1, p.94-100, 2016. DOI: http://dx.doi.org/10.14295/ oh.v22i1.855.

ENDRES, L.; MARROQUIM, P.M.G.; SANTOS, C.M. dos; SOUZA, N.N.F. de. Enraizamento de estacas de PauBrasil (Caesalpinia echinata Lam.) tratadas com ácido indolbutírico e ácido naftaleno acético. Ciência Rural, v.37, n.3, p.886-889, 2007. DOI: http://dx.doi.org/10.1590/ S0103-84782007000300046.

FACHINELLO, J.C.; HOFFMANN, A.; NACHTIGAL, J.C.; KERSTEN, E. Propagação de plantas frutíferas. Brasília: Embrapa Informação Tecnológica, 2005. 222p.

GONZÁLEZ H.; DÍAZ, T. Estaquillas lenosas de fácil enraizamiento: estúdio del esclerenquima. Calsadia, v.15, n.71-75. p.393-398, 1986
HARTMANN, H.T.; KESTER, D.E.; DAVIS JR., F.T.; GENEVE, R.L. Plant propagation: principles e practices. 8ed. Boston: Prentice Hall, 2011. 915 p.

HORMAETXE, K..; BECERRIL, J.M.; HERNÁNDEZ, A.; ESTEBAN, R.; GARCÍA-PLAZAOLA, J.I. Plasticity of photoprotective mechanisms of Buxus sempervirens L. leaves in response to extreme temperatures. Plant Biology, v.9, n.1, p.59-68, 2007. DOI: http://dx.doi. org/10.1055/s-2006-924456.

LIMA, D.M.D.; TANNO, G.N.; PURCINO, M.; BIASI, L.A.; ZUFFELLATO-RIBAS, K.C.; ZANETTE, F. Rooting of espinheira-santa (Maytenus ilicifolia Mart. ex Reissek) minicuttings on diferent substrates. Ciência e Agrotecnologia, v.33, n.2, p.617-623, 2009. DOI: http:// dx.doi.org/10.1590/S1413-70542009000200040.

LOSS, A.; TEIXEIRA, M.B.; ASSUNÇÃO, G.M.; HAIM, P.G.; LOUREIRO, D.C.; SOUZA, J.R. Enraizamento de estacas de Allamanda cathartica L. tratadas com ácido indol butírico (AIB). Revista Brasileira de Ciências Agrárias, v.3, n.4, p.313-316, 2008.

LOSS, A., TEIXEIRA, M.B., SANTOS, T.J.; GOMES, V.M.; QUEIROZ, L.H. Indução do enraizamento em estacas de Malvaviscus arboreus Cav. com diferentes concentrações de ácido indol butírico (AIB). Acta Scientiarum Agronomy, v.31, n.2, p.269-273, 2009. DOI: http://dx.doi.org/10.4025/actasciagron.v31i2.799.

LORENZI, H.; SOUZA, H.M. Plantas ornamentais no Brasil: arbustivas, herbáceas e trepadeiras. Nova Odessa: Instituto Plantarum de Estudos da Flora Ltda., 2013. 1120 p.

NIEMIERA, A.X. Selecting Landscape Plants: Boxwoods. 2012. Available in: <https://pubs.ext.vt.edu/ content/dam/pubs_ext_vt_edu/426/426-603/HORT-290. pdf $>$. Acessed on March 27, 2018.

NUNES GOMES, E.; KRINSKI, D. Propagação vegetativa de Piper amalago L. (Piperaceae) em função de tipos de estaca e substratos. Cultura Agronômica, v.25, n.2, p.199210, 2016 .

NUNES GOMES, E.; KRINSKI, D. Propagação vegetativa de Piper umbellatum L.(Piperaceae) em função de substratos e comprimentos de estacas. Scientia Agraria, v.17, n.3, p.31-37, 2016b. DOI: http://dx.doi.org/10.5380/ rsa.v17i3.49695.

OLIVEIRA, L.S.; DIAS, P.C.; ALMEIDA, M. Avaliação genética do enraizamento de miniestacas de uma procedência de Eucalyptus cloeziana. Pesquisa Florestal Brasileira, v.35, n.84, p.391-397, 2015. DOI: http://dx.doi. org/10.4336/2015.pfb.35.84.890. 
ORHAN, I.E.; ERDEM, S.A.; SENOL, F.S.; KARTAL, M.; SENER, B. Exploration of cholinesterase and tyrosinase inhibitory, antiprotozoal and antioxidant effects of Buxus sempervirens L. (boxwood). Industrial Cropsand Products, v.40, n.1, p.116-121, 2012. DOI: http://dx.doi. org/10.1016/j.indcrop.2012.03.004.

PIGATTO, G.B.; NUNES GOMES, E.: TOMASI, J.C.; FERRIANI, A.P.; DESCHAMPS, C. Effects of indolebutyric acid, stem cutting positions and substrates on the vegetative propagation of Stevia rebaudiana Bertoni. Revista Colombiana de Ciências Hortícolas, v.12, n.1, p.202-211, 2018. DOI: http://dx.doi.org/10.17584/ rcch.2018v12i1.6631.

SILVA, F.A.S.; AZEVEDO, C.A.V. The Assistat Software Version 7.7 and its use in the analysis of experimental data. African Journal of Agricultural Research, v.11, n.39, p.3733-3740, 2016. DOI: http://dx.doi.org/10.5897/ AJAR2016.11522.

SILVA, S.S.; KLOSOWSKI, A.C.; KOYAMA, R.; FABRI, C.A.; GOMES, L.L.; ZUFFELLATO-RIBAS, K.C. Enraizamento de estacas de Jasminum polyanthum tratadas com ácido indolbutírico. Scientia Agraria, v.13, n.1, p.1720, 2012. DOI: http://dx.doi.org/10.5380/rsa.v13i1.40855.
SMARSI, R.C.; CHAGAS, E.A.; REIS, L.L.; OLIVEIRA, G.F.; MENDONÇA, V.; TROPALDI, L.; PIO, R.; FILHO, J. A. S. Concentrações de ácido indolbutírico e tipos de substrato na propagação vegetativa de lichia. Revista Brasileira de Fruticultura, v.30, n.1, p.7-11, 2008. DOI: http://dx.doi.org/10.1590/S0100-29452008000100004.

TAIZ. L.; ZEIGER. E. Fisiologia vegetal. 5ed. Porto Alegre: Artmed, 2013. 918p.

TAKATA, W.H.S.; SILVA, E.G.; BARDIVIESSO, D.M. Enraizamento de estacas de Duranta repens Linn "Aurea" em função de doses de IBA. Revista Científica Eletrônica de Agronomia, v.21, n.1, p.1-9, 2012.

ZEM, M.L.; WISER, A.H.; ZUFFELLATO-RIBAS, K.C.; RADOMSK, M.I. Estaquia caulinar herbácea e semilenhosa de Drimys brasiliensis. Revista Ciência Agronômica, v.46, n.2, p.396-403, 2015. DOI: http:// dx.doi.org/10.5935/1806-6690.20150019. 